\title{
Optimisation and Comparative Evaluation of Fermentative Hydrogen Production using Pure and Co-culture of Clostridium beijerinckii and Enterobacter aerogenes
}

\author{
Ronald Ngulube \\ Department of Chemical Engineering, Copperbelt University, \\ P.O Box 21692, Kitwe, Zambia
}

Tel: 260-976-264-855 E-mail: ronald.ngulube@my.westminster.ac.uk

Julius J. Kanyembo

Department of Chemical Engineering, Copperbelt University, P.O Box 21692, Kitwe, Zambia

Tel: 260-557-767-693Ｅ-mail: kanyembo@cbu.ac.zm

Received: July 25, 2016 Accepted: January 13, 2017 Published: January 18, 2017

Doi: 10.5296/jab.v5i1.9763 URL: http://dx.doi.org/10.5296/jab.v5i1.9763

\begin{abstract}
Hydrogen, the only fuel to produce water as a by-product is seen as an ideal fuel for the future that can be produced from waste feedstock. The use of optimum bioreactor conditions and co-cultures with well-defined strains offer great potential to enhance hydrogen production due to diverse metabolic pathways. This study was aimed at determining the optimum $\mathrm{pH}$ and temperature on hydrogen production rate by Clostridium beijerinckii 6444 using glucose as substrate as well as investigating the influence of co-culture comprising of $C$. beijerinckii 6444 and Enterobacter aerogenes NCIMB 10102 on rate of hydrogen production and yield from glucose, molasses, crude glycerol and seed cake via dark fermentation. Batch fermentation in serum bottles was carried out in order to determine the total accumulative hydrogen gas, biomass concentration, and feedstock consumption in four days of fermentation. The co-culture was further scaled up to a $5 \mathrm{~L}$ fermenter. The optimum $\mathrm{pH}$ and temperature corresponding to 6.2 and $30{ }^{\circ} \mathrm{C}$ respectively were determined. The co-culture recorded the highest cumulative hydrogen volume $(66.5 \pm 4.2 \mathrm{ml})$ from crude glycerol though it did not
\end{abstract}


significantly increase the yields. The decrease in hydrogen production was observed as a result of formation of volatile fatty acids (acetic acid 1.5-3.1 g/l, butyric acid 3.2-5.6 g/l) among others which have inhibitory effects. The highest dead cell count of $3.4 \times 10^{8}$ cells $/ \mathrm{ml}$ indicated that $\mathrm{pH}$ was inhibitory. The scale-up showed an increase in the hydrogen production rate from $13.38 \mathrm{ml} / \mathrm{l} / \mathrm{hr}$ to $24.13 \mathrm{ml} / \mathrm{l} / \mathrm{hr}$ and yield of $1.37 \mathrm{~mol} \mathrm{H}_{2} / \mathrm{mol}$ glycerol after $24 \mathrm{hrs}$. The study showed that the co-culture of $C$. beijerinckii and E. aerogenes can be used to enhance hydrogen production from crude glycerol as a cheap carbon source.

Keywords: Biohydrogen, Dark fermentation, Biofuel, Co-culture, Crude Glycerol

\section{Introduction}

Hydrogen produced from biological process (biohydrogen) is deemed to be the fuel for the future that will replace petrochemical fuels owing to less energy intensive technologies involved (Bader et al., 2010). Hydrogen has also been reported to have high energy yield of $122 \mathrm{~kJ} / \mathrm{g}$ which is three times more energy than same weight/weight ratio of petrol and diesel (Azbar \& Levin, 2012). The energy can be converted to mechanical energy in combustion engines or used to generate electricity in proton exchange membrane fuel cells (Azbar \& Levin, 2012). When undergoes combustion only water vapour and heat energy are liberated without carbon monoxide, carbon dioxide, hydrocarbons and fine particles which are a nuisance to the environment (Bader et al., 2010). The transition to hydrogen fuel consumption in the transportation sector accounts for $80 \%$ of the total projected increase over the next 30 years (EIA, 2013 and European Commissions, 2014; Masset et al., 2012). The increase in demand globally for hydrogen use has been bolstered considerably in the recent years mainly as a result of the threats posed by fossil fuels in contributing to environmental pollution such as high concentration of carbon dioxide in the atmosphere, global warming concerns as well as political and economic reasons associated with it (Ding et al., 2009). The Netherlands Environmental Assessment Agency, (2013) report shows that global carbon emissions have increased by $1.4 \%$ and had reached 34.5 billion tons in 2012 . The report also indicates that carbon dioxide was a major constituent of the emissions contributing to the greenhouse effect, of which $57 \%$ was from combustion of fossil fuels.

Hydrogen is currently produced mainly from fossil fuels and energy-intensive processes such as gasification of coal, steam reformation-methane and electrolysis (Masset et al., 2012). The transition from non-renewable to renewable energy-based hydrogen has shown to provide a wide range of approaches such as light-dependent processes (e.g. photo-fermentation) or light-independent processes (i.e. dark fermentation) using microorganisms. However, dark fermentation is proving to be a more attractive process as it is capable of producing hydrogen without any constraints of light by utilising carbohydrates within a diverse range of organic waste feedstock and wastewater from sewage treatment, food, agriculture and municipal industries (Martínez-Pérez et al., 2007). Furthermore, dark fermentation has been reported to provide higher rates of production, more moderate reaction conditions and products that are easier to use in downstream processes compared to light dependant processes (Kothari et al., 2012; Levin et al., 2004).

Fermentative hydrogen producing microbes are capable of producing hydrogen in the exponential growth phase by oxidising glucose (Ding et al., 2009). Acetate and butyrate are 
associated to hydrogen production with theoretical maximum yields of 4 moles $\mathrm{H}_{2} / \mathrm{mol}$ glucose and 2 moles $\mathrm{H}_{2} / \mathrm{mol}$ glucose, respectively (Hawkes et al., 2002). Biohydrogen has reportedly been synthesised by several species of fermentative bacteria: Clostridium, Bacillus, Klebsiella, and Citrobacter (Lee et al., 2011). Pure cultures, in particular Clostridium species, are found to be promising fermentative hydrogen producers among other genera (e.g. Enterobacter, Bacillus) with the highest hydrogen yields of 1.61-2.36 $\mathrm{mol} \mathrm{H}_{2} / \mathrm{mol}$ hexose (Hawkes et al., 2002). In order to eliminate the use of reducing agents for oxygen removal to maintain anaerobic condition in the fermenter, a co-culture with well-defined hydrogen producers and a consortium of micro-organisms can be employed. Co-culture is reported to poses metabolic diversity and enzymatic reactions which allow co-cultures to utilise a variety of complex sugars (polysaccharides, disaccharides etc.) compared to pure cultures. Bader et al. (2010) reported that co-cultures are more robust to alterations in environmental conditions and are capable of metabolising pentose and hexose simultaneously. However, the 'creation' of stable artificial co-cultures has been reported to be problematic due to differences in growth rates, $\mathrm{pH}$ requirements, consumption and excessive production of metabolites between micro-organisms (Weibel, 2008). In other studies, syntrophic associations between clostridia species and facultative aerobes Enterobacter and Bacillus have significantly enhanced hydrogen production by consuming oxygen and preventing inhibition of $\mathrm{H}_{2}$ producing enzymes of the clostridia strain (Chou et al., 2011). The broad spectrum of applicable substrates in fermentative hydrogen production facilitates the possibility of combing the energetic utilization of biomass to hydrogen with the simultaneous treatment of waste materials (Quéméneur et al., 2011).

The study conducted by Hamilton et al. (2010) shows that hydrogen producing microbes are capable of regulating their metabolic pathway based on the concentration of liquid metabolites (volatile fatty acid and solvent) which is greatly influenced by environmental factors such as initial $\mathrm{pH}$, temperature and type of substrate. In an attempt to improve hydrogen production via dark fermentation, optimisation of these factors and careful selection of microbial consortia play a critical role in developing bioprocesses. In this study, the strategy to investigate the influence of co-culture comprising of $C$. beijerinckii and $E$ aerogenes from glucose, molasses, crude glycerol and seed cake was developed which included; 1) Optimisation of $\mathrm{pH}$ and temperature using a pure strain of $C$. beijerinckii from glucose. 2) Comparing the effect of the co-culture and their pure strains on hydrogen productivity and yield from different substrates using the optimum $\mathrm{pH}$ and temperature obtained in the previous set up. 3) Scaling up of the batch fermentation using the culture and the feedstock that gave the highest hydrogen yield so as to achieve better control of $\mathrm{pH}$ and agitation.

\section{Materials and Methods}

\subsection{Strains and Growth Media}

Pure strains of Clostrium beijerinckii 6444 and Enterobacter aerogenes NCIMB 10102 used for this study were purchased in powdered form from National Collection of Industrial Marine Bacteria (NCIMB, UK). C. beijerinckii was grown in a $125 \mathrm{ml}$ serum bottle containing $90 \mathrm{ml}$ tryptone yeast extract medium (TYG). The medium consisted of $3 \mathrm{~g} / \mathrm{l}$ 
tryptone, $5 \mathrm{~g} / 1$ yeast extract and $5 \mathrm{~g} / 1$ of glucose. Prior to inoculation, the serum vials were sealed with butyl rubber stoppers and flashed with nitrogen. The culture was then incubated at $37{ }^{\circ} \mathrm{C}$ for $48 \mathrm{hrs}$. E. aerogenes cells were revived using nutrient broth medium containing $15 \mathrm{~g} / 1$ peptone, $3 \mathrm{~g} / 1$ yeast extract, $6 \mathrm{~g} / \mathrm{l}$ sodium chloride and $1 \mathrm{~g} / 1 \mathrm{D}(+)$-glucose. The cells were then aerobically incubated at $30^{\circ} \mathrm{C}$ in a shaken flask on a rotary shaker at $150 \mathrm{rpm}$ for 48 hours.

\subsection{Resources}

All the materials and regents were purchased from Sigma Aldrich.

\subsection{Substrates}

In this study glucose, molasses, crude glycerol and seed cake were used as the carbon sources. The media for all the batch experiments were prepared by diluting glucose, molasses, crude glycerol and seed cake with distilled water to a concentration of $10 \mathrm{~g} / \mathrm{l}$ and autoclaved separately from MDT medium. The MDT medium used comprised of $5 \mathrm{~g} / \mathrm{l}$ casein peptone, $0.5 \mathrm{~g} / 1$ yeast extract, $1.2 \mathrm{~g} / 1 \mathrm{KH}_{2} \mathrm{PO}_{4}, 5.1 \mathrm{~g} / 1 \mathrm{Na}_{2} \mathrm{HPO}_{4}, 0.5 \mathrm{~g} / 1 \mathrm{~L}$-cysteine.

\subsection{Experimental Procedure}

\subsubsection{Optimization of $\mathrm{pH}$ and Temperature}

In order to determine the optimum $\mathrm{pH}$ and temperature for hydrogen production rate, a set of batch experiment were carried out in the $125 \mathrm{ml}$ serum vials using pure culture of $C$. beijerinckii 6444 and glucose. A working volume of $80 \mathrm{ml}$ was used consisting of $8 \mathrm{ml}$ of culture placed in nine serum bottles each containing $8 \mathrm{ml}$ glucose with a concentration of 10 $\mathrm{g} / \mathrm{l}$ in $64 \mathrm{ml}$ of fermentation medium (MDT).

Nitrogen was flushed into the vials to create anaerobic environment for culture. The experiments were in triplets with each set incubated at 20,30 and $40{ }^{\circ} \mathrm{C}$ on a rotary shaker at $150 \mathrm{rpm}$ with initial $\mathrm{pH}$ adjusted to 5.5, 6.2 and 7.0 for each set.

\subsubsection{Investigating the influence of Co-culture on hydrogen}

To study the influence of co-culture on hydrogen yield, four sets of experiment were used each comprising of a co-culture of $C$. beijerinckii and $E$. aerogene, a pure culture of $C$. beijerinckii and $E$. aerogenes and abiotic set up as controls. A working volume of $80 \mathrm{ml}$ was used with each set of experiment employing a different type of substrate as carbon source. The substrates used consisted of $8 \mathrm{ml}$ of $10 \mathrm{~g} / \mathrm{l}$ of glucose, molasses, crude glycerol and seed cake in $64 \mathrm{ml}$ MDT medium. The experiments were conducted aseptically under anaerobic conditions as described above at $\mathrm{pH}$ of 6.2 and temperature of $30^{\circ} \mathrm{C}$ on a rotary shaker at 150 rpm. 


\subsubsection{Scale-up of Hydrogen Production Using Co-culture}

The co-culture was scaled up to a $5 \mathrm{~L}$ fermenter operated at $150 \mathrm{rpm}$. The working volume was $4 \mathrm{~L}$ with $10 \mathrm{~g} / \mathrm{L}$ of glycerol concentration + MDT which was inoculated with $10 \% \mathrm{v} / \mathrm{v}$ of $C$. beijerinckii and E. aerogenes inoculum. All the parameters were measured as before: cell concentration, metabolites produced, $\mathrm{pH}$, and viability. The $\mathrm{pH}$ and percentage of hydrogen was measured using data logger National Instruments Lab VIEW programme.

\subsection{Sampling Analysis}

Biogas samples from the head-space of the serum vials were collected using a $1 \mathrm{ml}$ syringe fitted with a needle at pre-determined time intervals (every 24 hours) for four days. The optical density of the cultures was measured at $600 \mathrm{~nm}$ using spectrophotometer JENWAY model 6305. The $\mathrm{pH}$ changes over the experimental period were determined using a calibrated $\mathrm{pH}$ meter (Oakton benchtop series 700).

The phenol sulphuric acid method, as described by Dubois et al (1956), was used to determine the glucose concentration and sugars remaining in the culture on a daily basis. The concentration of glucose in molasses, crude glycerol and seed cake were measured in relation to sugar consumption. A standard curve with known concentrations of glucose $(0-100 \mathrm{mg} / \mathrm{L})$ was used to determine the amount of glucose remaining in the pure and co-culture medium. Residual liquid in samples from centrifugation at 13,000x g for 5 minutes was used in this assay.

The viability of cells in pure and co-cultures was determined from final samples using the LONZA trypan blue viability test. Samples were diluted tenfold and stained using $0.4 \%$ trypan blue (Sigma Aldrich). Dead cells were counted using haemocytometer at $\mathrm{x} 40$ magnification under light microscope (Zeiss primo star).

The hydrogen composition in $1 \mathrm{ml}$ of biogas injected from the head space was analysed and measured by means of gas chromatograph (SRI, model 310C) equipped with a thermal conductivity detector (GC-TCD) with the operational temperatures of injection port, oven, and the detector all set at $150^{\circ} \mathrm{C}$. The GC-TCD employs nitrogen as carrier gas at flow rate of $3.8 \mathrm{ml} / \mathrm{min}$. A one point calibration was performed using $50 \%$ hydrogen $/ 50 \%$ nitrogen to determine the peak area which corresponded to 50\% hydrogen within $1 \mathrm{ml}$ of injected calibration gas. Accordingly, the peak area represented the percentage composition of hydrogen gas within gaseous samples analysed

The liquid metabolites (fatty acids and solvents) concentration were analysed using the gas chromatography (Varian CP-3800) fitted with flame ionisation detector (GC-FID). The liquid samples were centrifuged at 13,000g (Thermo Scientific-Heraeus Pico) and filtered using a $0.2 \mu \mathrm{m}$ filter to remove collides and cells. Supernatant was stored in $1 \mathrm{mll}$ GC vials. The GC contained TCD with a column size of $30 \mathrm{~mm}$ length $\mathrm{x} 0.320 \mathrm{~mm}$ diameter $\mathrm{x} 0.50 \mu \mathrm{m}$ film HP INNOWax (Agilent J \& W GC columns). The mobile phase was hydrogen and helium gas with a flow rate of $2 \mathrm{ml} / \mathrm{min}$. The programme innowax was used, with the injector temperature of $220^{\circ} \mathrm{C}$ and detector temperature of $250^{\circ} \mathrm{C}$. The temperature of the chamber was maintained at $35^{\circ} \mathrm{C}$ from 0 - 5 min after which it increased constantly to $170{ }^{\circ} \mathrm{C}$ for 15 min. Unknown concentrations of metabolites were determined using analysed standard solutions of acetic acid, butyric acid and ethanol. 


\subsection{Statistical Analysis}

Statistics is used in analysing the results and average figures are expressed as mean values \pm SD.

\section{Results and Discussion}

\subsection{Optimisation of $\mathrm{pH}$ and Temperature for Hydrogen Production}

Table 1 shows the cumulative volume of hydrogen produced in four (4) days of fermentation using pure strain of $C$. beijerinckii from glucose in MDT fermentation medium. The buffering action of the MDT medium prevented any significant change in $\mathrm{pH}$, hence a constant $\mathrm{pH}$ range was observed in the four days of fermentation in all the cultures. The results indicate that the highest volume of hydrogen of $58.9 \pm 1.8 \mathrm{ml}$ was recorded at the temperature of $30{ }^{\circ} \mathrm{C}$ and $\mathrm{pH}$ of 6.2 compared to second highest performance of $52.4 \pm 2.0 \mathrm{ml}$ which was obtained at temperature of $40{ }^{\circ} \mathrm{C}$ and $\mathrm{pH}$ of 6.2 . The lowest cumulative hydrogen yield $(7.8 \pm 8.5 \mathrm{ml})$ was measured at the temperature of $20^{\circ} \mathrm{C}$ and $\mathrm{pH}$ of 5.5 for the same period of time. Butyric and acetic acid were the major metabolites produced in the cultures. The VFA showed an inhibitory effect on the cultures and hydrogen gas production, which was assessed by measuring dead cell counts.

Table 1. Cumulative hydrogen production at various temperature and $\mathrm{pH}$

\begin{tabular}{lll}
\hline Temperature $\left({ }^{\circ} \mathrm{C}\right)$ & $\mathrm{pH}$ & Cumulative $\mathrm{H}_{2}$ Production $(\mathrm{ml})$ \\
\hline \multirow{3}{*}{20} & 5.5 & $7.8 \pm 8.5$ \\
& 6.2 & $2.02 \pm 3.0$ \\
& 7.0 & $8.8 \pm 5.2$ \\
5.5 & $40.5 \pm 2.2$ \\
30 & 6.2 & $58.9 \pm 1.8$ \\
& 7.0 & $51.8 \pm 5.0$ \\
& 5.5 & $29.3 \pm 4.2$ \\
40 & 6.2 & $52.4 \pm 2.0$ \\
& 7.0 & $38.9 \pm 1.9$ \\
\hline
\end{tabular}

The results obtained compare well with the work of Tanisho et al. (1987) who reported hydrogen producing ability of $C$. beijerinckii from glucose to yield above $50 \%$ at optimum $\mathrm{pH}$ of 6.0-6.5 and temperature $30-37{ }^{\circ} \mathrm{C}$ compared to $\mathrm{pH}$ and temperature outside the respective specifications. Temperature and $\mathrm{pH}$ have been extensively studlied and reported to be critical parameters which have an effect on hydrogen production by altering metabolic pathways through inhibiting the enzymatic activity of microbes (Khanal et al., 2004; Masset et al., 2010). The activities of the essential enzyme hydrogenase and ionization state of the amino acids functional groups, capable of taking part in catalysis, are mainly dependant on changes in temperature and $\mathrm{pH}$ respectively. It has been reported that optimal $\mathrm{pH}$ and 


\section{Macrothink}

temperature promotes the production of acetic acid and butyric acid, both of which are associated with increased hydrogen yields (Khanal et al., 2004). However, the study conducted by Temudo et al. (2007) revealed that under unoptimal $\mathrm{pH}$, the hydrogen fermentation process shifted to solvent production or prolonged the lag phase. Furthermore, the lactate production was always observed together with sudden change of environment parameters, such as $\mathrm{pH}$, and temperature, which indicated the culture was not adapted to the new environment conditions.

\subsection{Comparative Hydrogen Production by Pure and Co-culture}

\subsubsection{Cumulative Hydrogen Production}

As represented in figure 1, there is significant variation in the hydrogen volume produced in four days of fermentation by co-culture of $C$. beijerinckii and E. aerogenes and pure culture of the same strains from glucose, molasses, glycerol and seed cake. The graphs generally indicate a pattern of lag phase, followed by a rapid hydrogen production phase and minimal production towards the end. The highest cumulative volumes of hydrogen gas production of $66.5 \pm 4.2 \mathrm{ml}$ and $61.2 \pm 3.2 \mathrm{ml}$ after $72 \mathrm{hrs}$ were recorded by co-culture from glycerol and molasses as shown in fig. $1 \mathrm{C}$ and $1 \mathrm{~B}$ respectively. Figure $1 \mathrm{~A}$ and $1 \mathrm{D}$ show that there is no significant difference in total cumulative $\mathrm{H}_{2}$ gas obtained between co-culture and pure culture of $C$. Beijerinckii. The lowest cumulative $\mathrm{H}_{2}$ gas production of $36.5 \pm 5.3 \mathrm{ml}$ was recorded using $E$. aerogenes from glucose as shown in Figure 1A. 
(A)

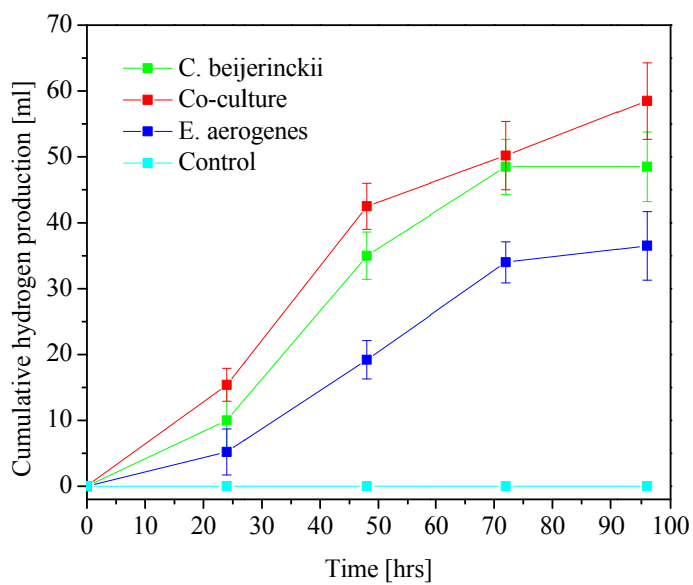

(C)

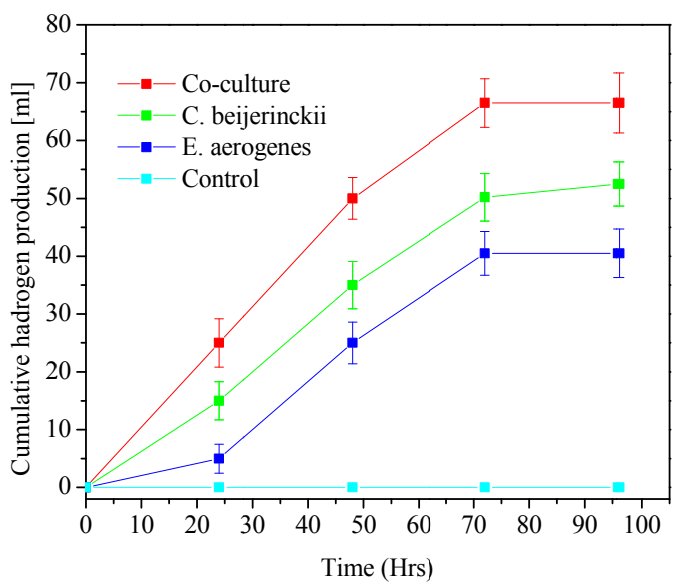

(B)

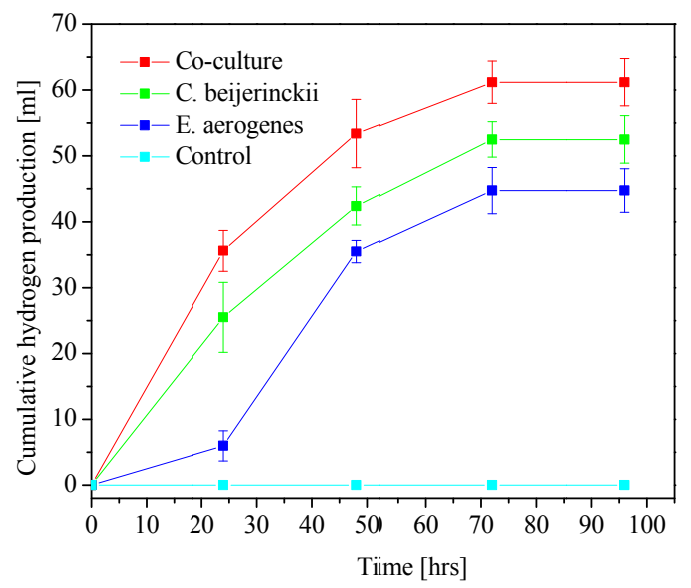

(D)

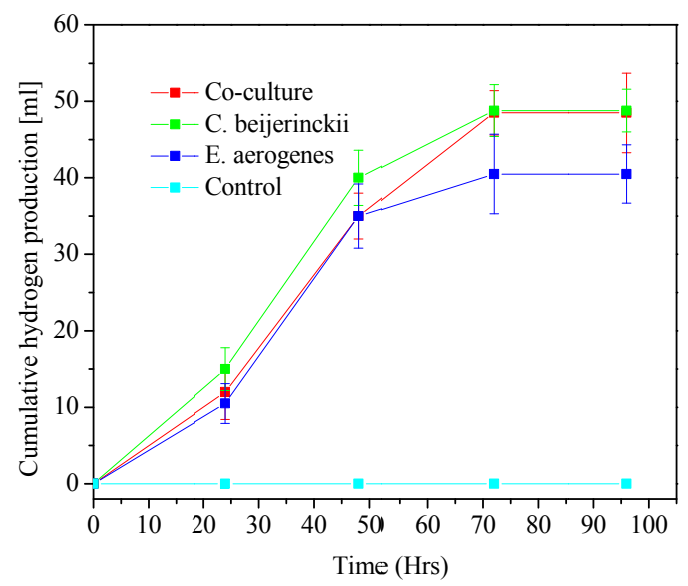

Figure 1. Investigation of cumulative hydrogen yield using co-culture of $C$. beijerinckii and $E$. aerogenes and their pure strains from different substrates (A) glucose (B) molasses (C) crude glycerol and (D) seed cake

It can be observed from the study that co-culture is capable of enhancing hydrogen productivity from glycerol. This could be attributed to the stability of the two strains in the co-culture as co-culture recorded the higher cell density compared to pure strains. Co-culture has been shown to have the ability to metabolise diverse range of sugars such as monosaccharides, disaccharides (fructose maltose, xylose etc.) from crude glycerol and molasses compared to pure strains (Chang et al., 2008). This is supported by the work conducted by Wang et al. (2008) which showed higher $\mathrm{H}_{2}$ production rates and yields from 
crude glycerol and molasses than glucose. In addition, Wang and Wan, (2009) observed that hydrogen yield could be improved by co-culturing a strict anaerobe Clostridium with a facultative Enterobactor that acts as scavengers of oxygen in the fermentation medium as oxygen sensitivity is a major limiting factor of most anaerobes. On the other hand, hydrogen production by pure cultures from waste feedstock has been a challenge as a result of the necessity for sterile conditions and in most cases incomplete utilisation of substrate (Temudo et al., 2007). However, the findings by Masset et al. (2012) showed a higher productivity of hydrogen of $1.5 \mathrm{~L}$ biogas/h using artificial co-cultures of known Clostridium species compared to pure cultures without the need for pre-treatments to hydrolyse complex compounds. This study demonstrates that all the cultures were capable of producing $\mathrm{H}_{2}$ gas from the substrates used. The decline in $\mathrm{H}_{2}$ production after day three could be as a result of nutrient and carbon source limiting environment along with inhibitory effects of low $\mathrm{pH}$ and VFA (acetic and butyric acids (Weibel, 2008).

\subsubsection{Metabolites, Culture Growth, Substrate Consumption and Cell Viability during} Fermentation

Figure 2, shows the graph of the main identified aqueous metabolites produced using co-culture of $C$. beijerinckii and E. aerogenes and their pure strains from glucose, crude glycerol, molasses and seed cake. The metabolites measured include acetic acid, butyric acid and ethanol. The graph shows similarities in the pattern of the aqueous metabolites produced with the highest concentration being that of butyric acid compared to that of acetic acid and ethanol. The co-culture from glycerol and molasses produced a greater quantity of butyric acid (5.6 and $5.4 \mathrm{~g} / \mathrm{l}$ respectively) while E. aerogenes from seed cake recorded the lowest (3.2 $\mathrm{g} / 1)$.

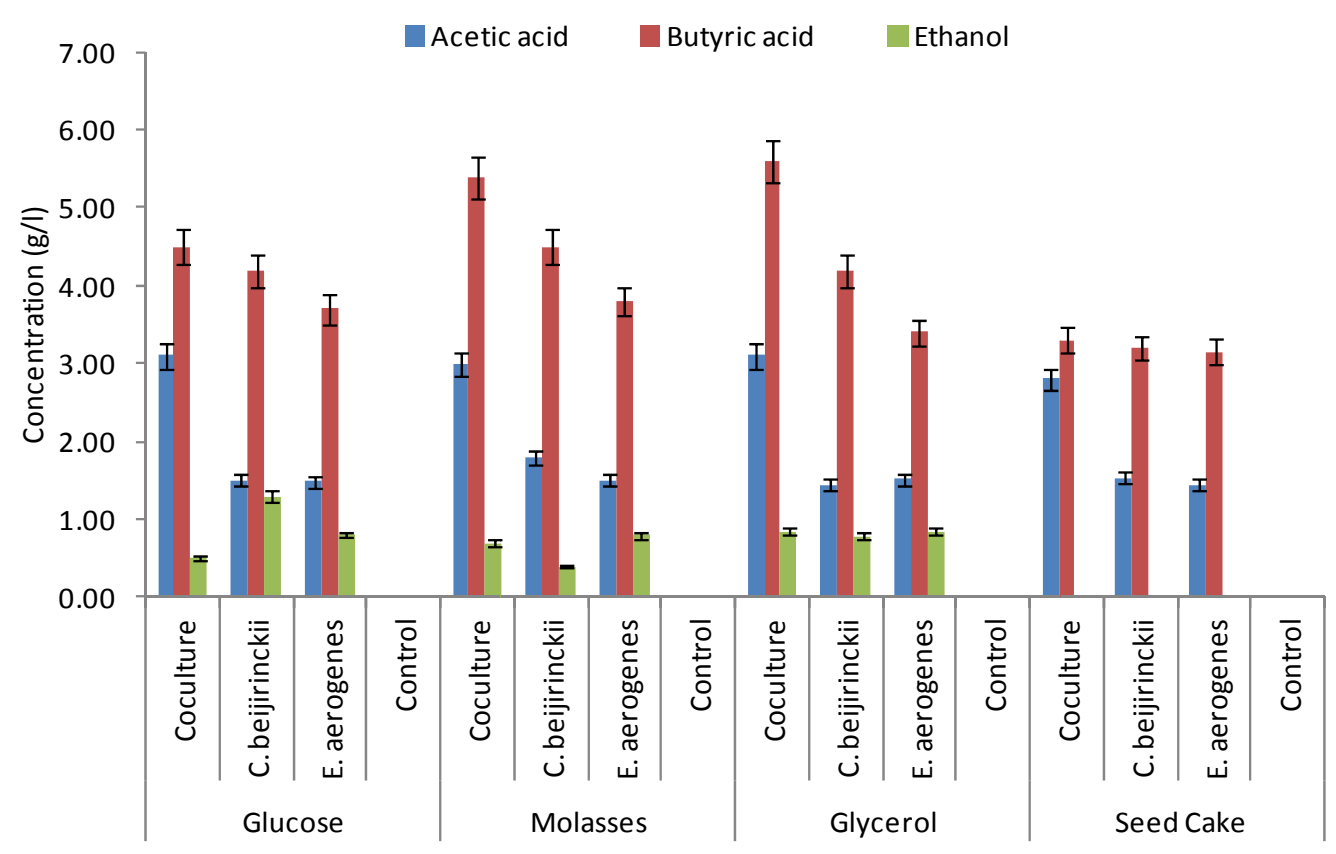

Figure 2. Aqueous metabolites produced using co-culture of C. beijerinckii and E. earogenes and their pure strains from glucose, molasses, crude glycerol and seed cake 
The figure suggests that hydrogen was directly produced through the butyric acid metabolic pathway and explains why higher total cumulative gas was measured by co-culture from glycerol and molasses and lowest by E. aerogenes from seed cake. The results indicate that the concentration of butyric acid produced was about twice higher than that of acetic acid, hence only 2 moles of $\mathrm{H}_{2}$ per hexose was produced. The high concentration of butyric acid obtained in the co-cultuture from crude glycerol and molasses correspond to high hydrogen yields. Masset et al. (2012) reported that C. beijerinckii strains have the ability to re-consume formate and lactate, producing additional hydrogen with carbon dioxide and butyrate as major by-products. The study carried out by Hu et al. (2013) also revealed that higher ratio of butyrate and acetate are associated with higher hydrogen yield while solvent reduced compounds such as ethanol, lactate and acetone are linked with lower hydrogen yield.

The trends from the OD indicated that the cell density was highest for co-cultures and remained stable during the last two days of fermentation compared to pure cultures. This suggests that the co-culture had reached the stationary phase within two days of fermentation. To the contrary, the growth of $C$. Beijerinckii and E. aerogenes showed a steady growth during the four days of fermentation implying that there was a slow growth. The trends of substrate consumption also revealed that the highest utilisation of glucose from glycerol was recorded after two days in all the cultures resulting in poor cell growth. In order to assess the viability of the cultures, dead cell count was used. Table 2 below shows the number of dead cells obtained at the end of fermentation. It can be seen that all the culltures showed high number of dead cells as a result of inhibitory effect toxic metabolites which leads to cell death.

Table 2. Dead cells at the end of fermentation

\begin{tabular}{ll}
\hline Culture & Dead Cell count $\mathbf{x} \mathbf{1 0}^{\mathbf{8}}$ (cells/ml) \\
\hline Co-culture & $3.4 \pm 2.32$ \\
C. beijerinckii & $3.1 \pm 1.94$ \\
E. earogenes & $2.3 \pm 0.96$ \\
Control & $0 \pm 0$ \\
\hline
\end{tabular}

\subsubsection{Scale up: Hydrogen Production Rate, Yield and Metabolites}

The hydrogen production by co-culture from glycerol was scaled up to $5 \mathrm{~L}$, batch fermenter so as to increase hydrogen production rate per litre. The profile on figure 3 indicates a lag phase which was followed by rapid evolution of hydrogen from $18 \%$ to $97 \%$ during exponential phase between 20-27 hrs. This was accompanied by decrease in $\mathrm{pH}$ from 7.2 to around 6.1-6.3 optimal range. The highest gas composition of $99 \%$ hydrogen was recorded after 28 hrs at approximately maximum biomass level of $7900 \mathrm{mg} / \mathrm{l}$ as shown in figure 4 . This shows that as the biomass concentration increases, the hydrogen production increases correspondingly. After $48 \mathrm{hrs}$, a decrease in \% hydrogen production was measured as a result of exhaustion of carbohydrate coupled with toxic effects from acidic metabolites. Liquid samples taken after 16, 32 and 48 hrs gave 524.5, 164.6 and $40.2 \mathrm{mg} / 1$ carbohydrate content 


\section{Macrothink}

and $0.412,0.289$ and 0.025 absorbance readings for biomass analysis (x 50 dilution factor) respectively.

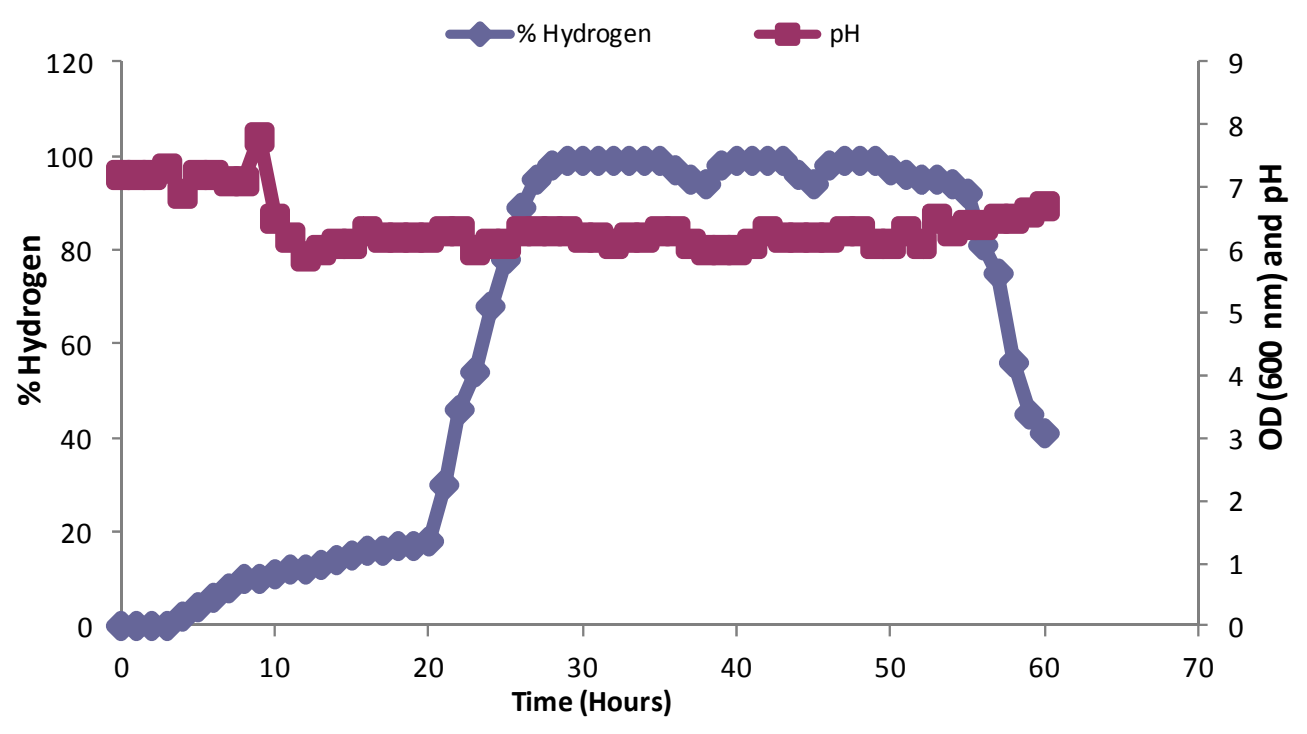

Figure 3. Cumulative hydrogen production using co-culture from crude glycerol

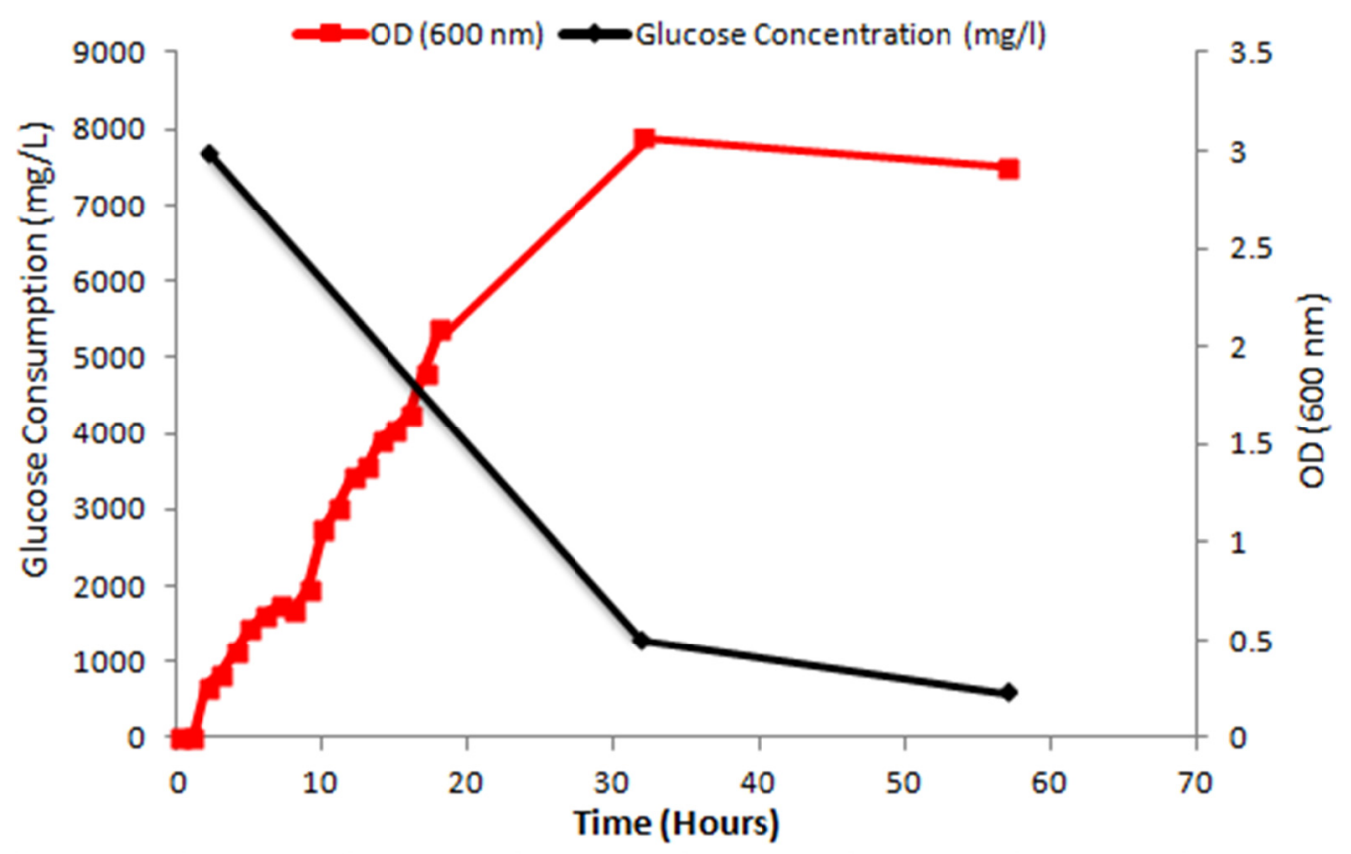

Figure 4. OD and glucose consumption of co-culture 5-litre batch fermentation

The study recorded an increase in hydrogen productivity by $10.75 \mathrm{ml} / \mathrm{l} / \mathrm{hr}$ from $13.38 \mathrm{ml} / \mathrm{l} / \mathrm{hr}$ and hydrogen yield $\left(1.37 \mathrm{molH}_{2} / \mathrm{mol}\right.$ glycerol $)$ after $24 \mathrm{hrs}$. This could be attributed to slow release of glucose from the breakdown of crude glycerol. This was followed by an increase in 
hydrogen generation and consequently a formation of VFA which led to decline in hydrogen production. The build up in partial pressure of hydrogen could have caused the alteration in metabolic pathway from acid production to ethanol production as evident from the rise of ethanol concentration. A report carried out by Argun and Kargi, (2011) showed that large-scale batch fermentation reduce the hydrogen yields due to inhibition of $\mathrm{H}_{2}$ formation by excessive feedstock and metabolites produced. Table 3 below shows hydrogen production rate and yield obtained during batch fermentation at time 24 and $48 \mathrm{hrs}$. The final cell dead count is also indicated.

Table 3. Concentration of metabolites, hydrogen production rate, yield and final dead cell count in a 5-litre batch fermentation

\begin{tabular}{|c|c|c|c|c|c|c|}
\hline $\begin{array}{l}\text { Time } \\
\text { (Hours) }\end{array}$ & $\begin{array}{l}\text { Acetic } \\
\operatorname{acid}(g / l)\end{array}$ & $\begin{array}{l}\text { Butyric } \\
\text { acid (g/l) }\end{array}$ & $\begin{array}{l}\text { Ethanol } \\
(\mathrm{g} / \mathrm{l})\end{array}$ & $\begin{array}{l}\mathrm{H}_{2} \\
\text { Production } \\
\text { rate } \mathrm{ml} / \mathrm{hr} \text { ) }\end{array}$ & $\begin{array}{l}\mathrm{H}_{2} \text { yield } \\
(\mathrm{mol} \\
\mathrm{H}_{2} / \mathrm{mol} \\
\text { glycerol) }\end{array}$ & $\begin{array}{l}\text { Final dead } \\
\text { cell count } \\
(\text { cells } / \mathbf{m l})\end{array}$ \\
\hline $0-24$ & 3.65 & 7.26 & 0.41 & 13.38 & & \\
\hline $24-48$ & 2.14 & 8.91 & 3.07 & 24.13 & 1.37 & $2.12 \times 10^{8}$ \\
\hline
\end{tabular}

The GC analysis for the scale-up study showed variations higher concentration of acetic acid compared to butyric acid and this corresponds to higher $\mathrm{H}_{2}$ yield. $65 \%$ of metabolite was acetic acid, thus hydrogen was produced with theoretical maximum value of $4 \mathrm{~mol} \mathrm{H}_{2} / \mathrm{mol}$ glucose (Reith et al., 2003). A variation in metabolites was observed as crude glycerol comprises complex mixtures of different sugars. Quéméneur et al. (2011) reported various metabolite concentrations i.e. acetic acid, butyric acid and ethanol from different carbohydrates and improved hydrogen production from long chain-length sugars. The amount of acetic acid produced between $24-48 \mathrm{hrs}$ is directly proportional to the rate of production of hydrogen $(24.13 \mathrm{ml} / \mathrm{hr})$ and yield $\left(1.37 \mathrm{~mol} \mathrm{H}_{2} / \mathrm{mol}\right.$ glycerol $)$. The dead cell count indicates the inhibition of cell culture due to toxic metabolites.

\section{Conclusion}

The investigation shows that co-culture of $C$. beijerinckii and E. aerogenes together with its pure strains are capable of producing hydrogen from glucose, molasses, crude glycerol and seed cake. The results also indicate that co-culture can be used to enhance hydrogen productivity and yield from crude glycerol at optimum $\mathrm{pH}$ and temperature of 6.2 and $30{ }^{\circ} \mathrm{C}$ respectively. Hydrogen production from all the feedstock used follows a similar pattern of lag phase, followed by a rapid hydrogen production phase and minimal production towards the end due to exhaustion of glucose and toxic effects acidic metabolites. The highest cumulative volume of hydrogen gas production of $66.5 \mathrm{ml}$ and $61.2 \mathrm{ml}$ after $72 \mathrm{hrs}$ was recorded by co-culture from glycerol and molasses respectively. The scale-up showed an increase in the hydrogen production rate from $13.38 \mathrm{ml} / \mathrm{l} / \mathrm{h}$ to $24.13 \mathrm{ml} / \mathrm{l} / \mathrm{h}$ in $24 \mathrm{hrs}$. The yield was determined to be $1.37 \mathrm{~mol} \mathrm{H}_{2} / \mathrm{mol}$ glycerol. 


\section{Acknowledgements}

I would like to earnestly express my gratitude to the University of Westminster where this study was conducted. I am also grateful to Dr. G. Kyazze who supervised this research project and not forgetting my colleagues Devlin, Angel, Nayanan and Devon for constructive and stimulating discussions pertaining to this study. Lastly but not the least my beloved ones Priscilla, Nastaziah and Rony for the support and encouragement rendered to me.

\section{References}

Argun, H., \& Kargi, F. (2011). Bio-hydrogen production by different operational modes of dark and photo-fermentation: an overview. International Journal of Hydrogen Energy, 36, 7443-59. https://doi.org/10.1016/j.ijhydene.2011.03.116

Argun, H., Kargi, F., \& Kapdan, I. (2008). Light fermentation of dark fermentation effluent for bio-hydrogen production by different Rhodobacter species at different initial volatile fatty acid (VFA) concentrations. International Journal of Hydrogen Energy, 33, 7405-7412. https://doi.org/10.1016/j.ijhydene.2008.09.059

Azbar, N., \& Levin, D. B. (2012). State of the Art and Progress in Production of Biohydrogen, Bentham Science Publishers. https://doi.org/10.2174/97816080522401120101

Bader, J., Mast-Gerlach, E., Popović, M., Bajpai, R., \& Stahl, U. (2010). Relevance of microbial coculture fermentations in biotechnology. J Appl Microbiol, 109, 371-387. https://doi.org/10.1111/j.1365-2672.2009.04659.x

Chang, J., Chang, C., Chou, J. C., Ho, C., Chen, W., Lay, J., \& Huang, C. (2008). Syntrophic co-culture of aerobic Bacillus and anaerobic Clostridium for bio-fuels and bio-hydrogen production. International Journal of Hydrogen Energy, 33, 5137-46. https://doi.org/10.1016/j.ijhydene.2008.05.021

Chen, W., Chen, Z., Tseng, Z., Lee, K., \& Chang, J. (2005). Fermentative hydrogen production with CGS5 isolated from anaerobic sewage sludge. International Journal of Hydrogen Energy, 30, 1063-1070. https://doi.org/10.1016/j.ijhydene.2004.09.008

Chou, C. H., Han, C. L., Chang, J. J., \& Lay, J. J. (2011). Co-culture of Clostridium beijerinckii L9, Clostridium butyricum M1 and Bacillus thermoamylovorans B5 for converting yeast waste into hydrogen. International journal of hydrogen energy, 36, 13972-83. https://doi.org/10.1016/j.ijhydene.2011.03.067

Ding, J., Liu, B-F., Ren, N-Q., Xing, D-F., Guo, W-Q., Xu, J-F., \& Xie, G-J. (2009). Hydrogen production from glucose by co-culture of Clostridium Butyricum and immobilized Rhodopseudomonas faecalis RLD-53. International Journal of Hydrogen Energy, 34, 3647-3652. https://doi.org/10.1016/j.ijhydene.2009.02.078

Dubois, M., Gilles, K. A., Hamilton, J. K., Rebers, P. T., \& Smith, F. (1956). Colorimetric method for determination of sugars and related substances. Analytical Chemistry, 28, 350-56. https://doi.org/10.1021/ac60111a017

EIA. (2013). International energy outlook 2013 - U.S Energy information administration. Retrieved13 December, 2014, from http://www.eia.gov/forecasts/ieo/index.cfm

European Commissions. (2014). EU greenhouse gas emissions and targets. Retrieved13 December, 2014, from http://ec.europa.eu/clima/policies/g-gas/index_en.htm 
Guo, X. M., Trably, E., Latrille, E., Carrere, H., \& Steyer, J. P. (2010). Hydrogen production from agricultural waste by dark fermentation: A review. International Journal of Hydrogen Energy, 35, 10660-10673. https://doi.org/10.1016/j.ijhydene.2010.03.008

Hamilton, C., Hiligsmann, S., Beckers, L., Masset, J., Wilmotte, A., \& 'Thonart, P. (2010). Optimization of culture conditions for biological hydrogen production by Citrobacter freundii CWBI952 in batch, sequenced-batch and semicontinuous operating mode. International Journal of Hydrogen Energy, 35, 1089-1098. https://doi.org/10.1016/j.ijhydene.2009.10.073

Hawkes, F. R., Dinsdale, R., Hawkes, D. L., \& Hussy, I. (2002). Sustainable fermentative hydrogen production: challenges for process optimization. International Journal of Hydrogen Energy, 27, 1339-47. https://doi.org/10.1016/S0360-3199(02)00090-3

Hu, C. C., Giannis, A., Chen, C. L., Qi, W., \& Wang, J. Y. (2013). Comparative study of biohydrogen production by four dark fermentative bacteria. International Journal of Hydrogen Energy, 38, 15686-92. https://doi.org/10.1016/j.ijhydene.2013.03.131

Khanal, S. K., Chen, W., Li, L., \& Sung, S. (2004). Biological hydrogen production: effects of $\mathrm{pH}$ and intermediate products. International Journal of Hydrogen Energy, 29, 1123-31.

Kothari, R., Singh, D. P., Tyagi, V. V., \& Tyagi, S. K. (2012). Fermentative hydrogen production - An alternative clean energy source. Renewable and Sustainable Energy Reviews, 16, 2337-46. https://doi.org/10.1016/j.rser.2012.01.002

Lee, D. J., Show, K., \& Su, A. (2011). Dark fermentation on biohydrogen production: Pure culture. Bioresour Technol, 102, 8393-8402. https://doi.org/10.1016/j.biortech.2011.03.041

Levin, D. B., Pitt., L., \& Love, M. (2004). Biohydrogen production: prospects and limitations to practical application. International Journal of Hydrogen Energy, 29, 173-85. https://doi.org/10.1016/S0360-3199(03)00094-6

Lin, P.-Y., Whanga, L-M., Wua, W-R., Rena, W-J., Hsiaoa, C-J., Lia, S-L., \& Chang, J-S. (2007). Biological hydrogen production of the genus Clostridium: Metabolic study and mathematical model simulation. International Journal of Hydrogen Energy, 32, 1728-1735. https://doi.org/10.1016/j.ijhydene.2006.12.009

Martínez-Pérez, N., Cherryman, S. J., Premier, G. C., Dinsdale, R. M., Hawkes, D. L., Hawkes, E. R., Kyazze, G., \& Guwy, A. J. (2007). The potential for hydrogen-enriched biogas production from crops: Scenarios in the UK. Biomass and Bioenergy, 31, 95-104. https://doi.org/10.1016/j.biombioe.2006.07.003

Masset, J., Hiligsmann, S., Hamilton, C., Beckers, L., Franck, F., \& Thonart, P. (2010). Effect of $\mathrm{pH}$ on glucose and starch fermentation in batch and sequenced-batch mode with a recently isolated strain of hydrogen-producing Clostridium butyricum CWBI1009. Int J Hydrogen Energy, 35, 3371-3378. https://doi.org/10.1016/j.ijhydene.2010.01.061

Masset, J., Calusinska, M., Hamilton, C., Hiligsmann, S., Joris, B., Wilmotte, A., \& Thonart, P. (2012). Fermentative hydrogen production from glucose and starch using pure strains and artificial co-cultures of Clostridium spp. Biotechnol Biofuels, 5, 35. https://doi.org/10.1186/1754-6834-5-35

Momirlan, M., \& Veziroglu, T. N. (2002). Current status of hydrogen energy. Renewable and Sustainable Energy Reviews, 6, 141-79. https://doi.org/10.1016/S1364-0321(02)00004-7 
Nath, K., \& Das, D. (2004). Improvement of fermentative hydrogen production: various $\begin{array}{llll}\text { approaches. Appl } & \text { Microbiol } & \text { Biotechnol, 65-529. }\end{array}$ https://doi.org/10.1007/s00253-004-1644-0

Netherlands Environmental Assessment Agency. (2013). Trends in Global Co2 emissions2013 report. Retrieved 13 December, 2014, from http://edgar.jrc.ec.europa.eu/news_docs/pbl-2013-trends-in-global-co2-emiissions-2013-report -1148.pdf

Ntaikou, I., Antonopoulou, G., \& Lyberatos, G. (2010). Biohydrogen Production from Biomass and Wastes via Dark Fermentation: A Review. Waste and Biomass Valorization, 1, 21-39. https://doi.org/10.1007/s12649-009-9001-2

O-thong, S., Mamimin, C., \& Prasertsan, P. (2011). Effect of temperature and initial pH on biohydrogen production from palm oil mill effluent: long-term evaluation and microbial community analysis. Electronic Journal of Biotechnology, 14(5). https://doi.org/10.2225/vol14-issue5-fulltext-9

Quéméneur, M., Hamelin, J., Benomar, S., Guidici-Orticoni, M., Latrille, E., Steyer, J., \& Trably, E. (2011). Changes in hydrogenase genetic diversity and proteomic patterns in mixed-culture dark fermentation of mono-, di- and tri-saccharides. Intermational Journal of Hydrogen Energy, 36, 11654-65. https://doi.org/10.1016/j.ijhydene.2011.06.010

Ren, N., Guo, W., Liu, B., Cao, G., \& Ding, J. (2011). Biological hydrogen production by dark fermentation: challenges and prospects towards scaled-up production. Curr Opin Biotechnol, 22, 365-370. https://doi.org/10.1016/j.copbio.2011.04.022

Reith, J., Wijffels, R., \& Barteb, H. (2003). Bio-methane \& Bio-hydrogen: Status and perspectives of biological methane and hydrogen production. http://gasunie.eldoc.ub.rug.nl/root/2003/3339875/

Savichtcheva, O., Joris, B., Wilmotte, A., \& Calusinska, M. (2010). Novel FISH and quantitative PCR protocols to monitor artificial consortia composed of different hydrogen-producing Clostridium spp. Int $J$ Hydrogen Energy, 36, 7530-7542. https://doi.org/10.1016/j.ijhydene.2011.03.097

Temudo M. F., Kleerebezem, R., \& Van Loosdrecht, M. (2007). Influence of the pH on (open) mixed culture fermentation of glucose: A chemostat study. Biotechnology and Bioengineering, 98, 69-79. https://doi.org/10.1002/bit.21412

Weibel, D. B. (2008). Building communities one bacterium at a time. Proceedings of the National Academy of Sciences, 105, 18075-76. https://doi.org/10.1073/pnas.0810201106

Zhou, P., Elbeshbishy, E., \& Nakhlaa, G. (2013). Optimization of biological hydrogen production for anaerobic co-digestion of food waste and wastewater biosolids. Bioresour Technol, 130, 710-718. https://doi.org/10.1016/j.biortech.2012.12.069

\section{Copyright Disclaimer}

Copyright reserved by the author(s).

This article is an open-access article distributed under the terms and conditions of the Creative Commons Attribution license (http://creativecommons.org/licenses/by/3.0/). 